\title{
Shallow Marine Cretaceous Sequences and Petroleum Geology of the Onshore Portion Rio del Rey Basin, Cameroon, Gulf of Guinea
}

\author{
Olivier Anoh Njoh, Agbor Junior Taku \\ Department of Geology, University of Buea, Buea, Cameroon \\ Email: njoh68@yahoo.fr
}

Received 8 December 2015; accepted 19 February 2016; published 22 February 2016

Copyright (C) 2016 by authors and Scientific Research Publishing Inc.

This work is licensed under the Creative Commons Attribution International License (CC BY). http://creativecommons.org/licenses/by/4.0/

(c) (7) Open Access

\begin{abstract}
Extensive thickly folded sedimentary sequences are exposed onshore of the Rio del Rey Basin contrary to previous reports of their rarity. Shales predominate, frequently intercalated by marlstones, sandstones, mudstones, limestones and marls and have been intruded in places by volcanic rocks of the Cameroon Volcanic Line (CVL). An integration of lithostratigraphic, paleontologic, granulometric and petrographic data generated from field and laboratory studies, permitted the identification of eleven (11) lithofacies which were subsequently grouped into three facies associations to facilitate the reconstruction of the paleo-depositional environment. Graphic logs constructed from the different outcrops studied revealed general coarsening upward sequences. Mega body fossils recovered from these sediments include severely altered, ferruginized fish and turtle-like heads, bivalve shells and moulds. Two bivalve taxa were identified: Exogyra ponderosa (Roemer) and members of the Venericardiinae sub-family. Textural and mineralogical details were obtained from granulometric and thin sections (microscopy). Interpretation of these data inferred an open relatively deeper marine, probably middle neritic to near shore transitional intertidal environments into which these sediments previously dated as Lower to Upper Cretaceous were deposited. Elements of a possible petroleum system: source and reservoir rocks, migratory pathways and trapping conditions, have been pointed out and thought to exist in space and time.
\end{abstract}

\section{Keywords}

Cretaceous, Depositional Environment, Lithofacies, Petroleum System, Rio del Rey

\section{Introduction}

The Rio del Rey Basin occupies the extreme south-western part of Cameroon (Figure 1), in the Gulf of Guinea.

How to cite this paper: Njoh, O.A. and Taku, A.J. (2016) Shallow Marine Cretaceous Sequences and Petroleum Geology of the Onshore Portion Rio del Rey Basin, Cameroon, Gulf of Guinea. Open Journal of Marine Science, 6, 177-192.

http://dx.doi.org/10.4236/ojms.2016.62014 


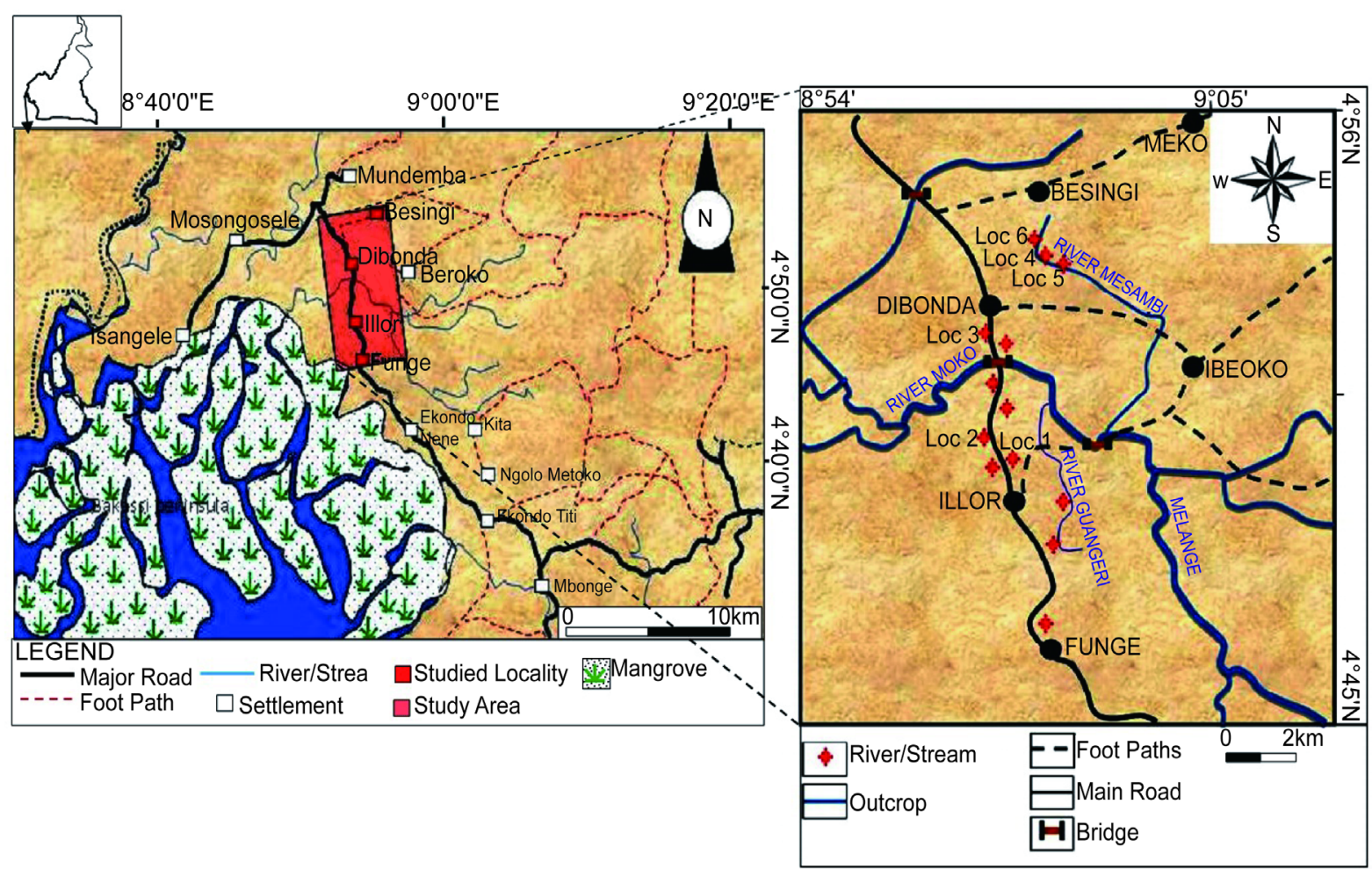

Figure 1. Map of the Rio del Rey Basin (modified from [48]) including the study area and the outcrop locations.

It is one of two coastal sedimentary basins, the other being the Douala-Kribi/Campo Basin both of which are the country's hydrocarbon producers. The sedimentary fills of this basin consist of Cretaceous basal conglomerates, sandstones, shales and carbonate rocks that outcrop on the northern onshore flank of the basin and the Tertiary units consist mainly of deltaic facies and are generally found offshore. [1]-[4] noted the close association of the Tertiary units of the basin with the Niger Delta, of which it is part and constitutes the eastern extension of the latter across the Nigeria/Cameroon border. The Cretaceous interval on the other hand is linked to the Calabar Flank constituting part of a continuous sedimentary pile along the coastal margins of this central West African sub-region.

The Rio del Rey Basin accounts for over 70\% of Cameroon's hydrocarbon production with the oilfields located exclusively offshore and within the Tertiary strata for which this basin is known. Consequently, the lithostratigraphy and petroleum geology of the Tertiary units are similar to those of the Niger Delta and have been well studied though, only a few of such studies and their results are published. Comparatively, very little information is available in literature on the geology of the predominantly Cretaceous strata outcropping along the northern flank. [5]-[7] stressed on the rarity of sedimentary exposures onshore of the basin, noting the thick vegetation cover, intense weathering, thick overburden, extensive swamps along the valleys of the several rivers in their third stage characterizing this area. Apart from the recent deltaic sands that are loose and widespread probably as overbank flow deposits, the Tertiary sediments of this basin occur exclusively offshore [2] [8]. Contrarily to these early studies, [4] and many others have revealed that northward, away from the swamps and towards the edge of the basin, thick sedimentary strata occur and have been folded, uplifted and are well exposed along deeply incised river channels. Sections encountered along such river valleys and others along very steep hillsides though densely vegetated and intensely weathered, expose sedimentary sequences, some well over 32 m high [9].

Some of the recent studies [4] [8] have focused on the utility of foraminifera and palynology in assigning ages to these Cretaceous exposures encountered in this part of the basin. The dated sections have also been correlated with other age equivalent units already well established in neighbouring basins with the aim of progressively building up a credible Cretaceous stratigraphy of this basin that is still inexistent. Other publications have rather focused on the Tertiary offshore part of the basin. [1] highlighted the petroleum geology of some offshore del- 
taic sequences; [10] used the Rio del Rey Basin to exemplify deep sea petroleum exploration in the Gulf of Guinea. Analyses of the production trend in this basin from several unpublished reports have shown a steady decline that calls for concern. Alerted by this decline, some petroleum companies are now turning their attention to non-prospected areas like this onshore part of the basin.

The present work therefore is part of the on-going investigations of this onshore part of the basin so as to contribute and ease exploration activities currently in progress. The aim is to carry out an intensive search and locate new sedimentary outcrops, describe and analyse their constituent lithofacies and reconstruct their paleodepositional environments in view of throwing some light into the petroleum potentials of this part of the Rio del Rey Basin. The recent granting of hydrocarbon exploration permits in the onshore sector has rejuvenated geologic studies in this area wherein the Cretaceous rocks of the basin outcrop. Poor road network, heavy rainfall, high rate of weathering, thick tropical evergreen forest, extensive mangrove swamps and the many rivers at their third stage, characterize this region and partly account for the stagnation of geologic field studies.

\section{Geologic Setting}

The tectonic and stratigraphic evolutionary history of the Rio del Rey Basin like the other basins lining the West African coast is closely linked with the rifting processes that led to the opening of the South Atlantic, the consequent separation of South America from the African continent and the formation of the Gulf of Guinea [11]. Several authors [12]-[19], have reported on the tectonic processes that started from the Late Jurassic through Early Cretaceous including; the syn-rift sequence (Barremian-Aptian), rift-drift transition phase (mid-late Aptian) and a post-rift phase (Albian - Present) which comprises three stages of drift; Drift I (Albian - Coniacian, Drift II (Santonian - Eocene) Drift III (Eocene - Pleistocene).

The basin has accumulated well over $6000 \mathrm{~m}$ thick of marine and non-marine clastic and biogenic sediments that range in age from Neocomian to Recent. Predominantly Cretaceous sedimentary rocks outcrop on the onshore part of the basin while the Tertiary rocks overlie the Cretaceous mainly as progradational deltaic sequences off-shore. The stratigraphy of the basin (Figure 2) is still very incomplete, because the Cretaceous sedimentary sequences are yet to be studied in detail. However, directly and unconformably overlying the Precambrian basement is the basal conglomeratic unit of Neocomian-Albian continental, fluvio-lacustrine mudstones, sandstones and conglomerates. This unit was originally distinguished from the overlying Albian-Maastrichtian deposits [7]. Using palynological data, [9] dated Albian-Cenomanian strata comprising of thin beds of limestone inter-bedded within a predominantly dark-grey to black shales in the northern part of the basin. The Turonian-Coniacian sedimentary unit was described as part of the Upper Cretaceous sediments in this basin [2]. The unit is made up of dark-grey calcareous shales, frequently inter-bedded by marlstone, limestone and siltstone. Recent studies have established the Campanian-Maastrichtian unit which is tentatively and informally called the "Kita Formation" [4]. The Paleocene - Recent Akata Formation is a pro-deltaic marine shale unit overlying the Cretaceous sediments. It is overlain by the Oligocene-Miocene to Recent alternating sands and shale paralic deltaic front unit, Agbada Formation. The Pliocene-Recent Benin Sandstone Formation is the uppermost unit, which comprises continental to coastal plain sandstones in this basin (Figure 2).

\section{Materials and Methods}

The present work is basically field based and materials considered for laboratory analyses are sedimentary rock samples obtained from the six outcrops under investigation within the study area. These outcrops occur mainly as cliffs along incised river valleys, steep hillsides slopes and roadside cut exposures. They include the Djega shale outcrop, the Djega sandstone road-cut (Figure 3(a)), the Dibonda Hill road exposure and the outcrops along the banks of the Messambi River (Figure 3(b)). Three distinct outcrop sections occur at different locations along both banks of River Messambi namely: Messambi I (downstream), Messambi II (middle) and Messambi III (upstream), respectively.

All the outcrops identified during the field mapping stage were located (mapped), logged and detailed lithostratigraphic descriptions and analyses were carried out during which the lithofacies were identified and grouped into facies associations. Granulometric properties of the rocks were investigated under low powered microscopy of crushed samples in the laboratory of the Department of Geology, University of Buea. Thin sections of the samples collected were prepared in the LTM laboratory of IRGM Nkolbisong Yaoundé from which detailed mineralogical characteristics of the rocks were investigated. The lithologic sections of the different 


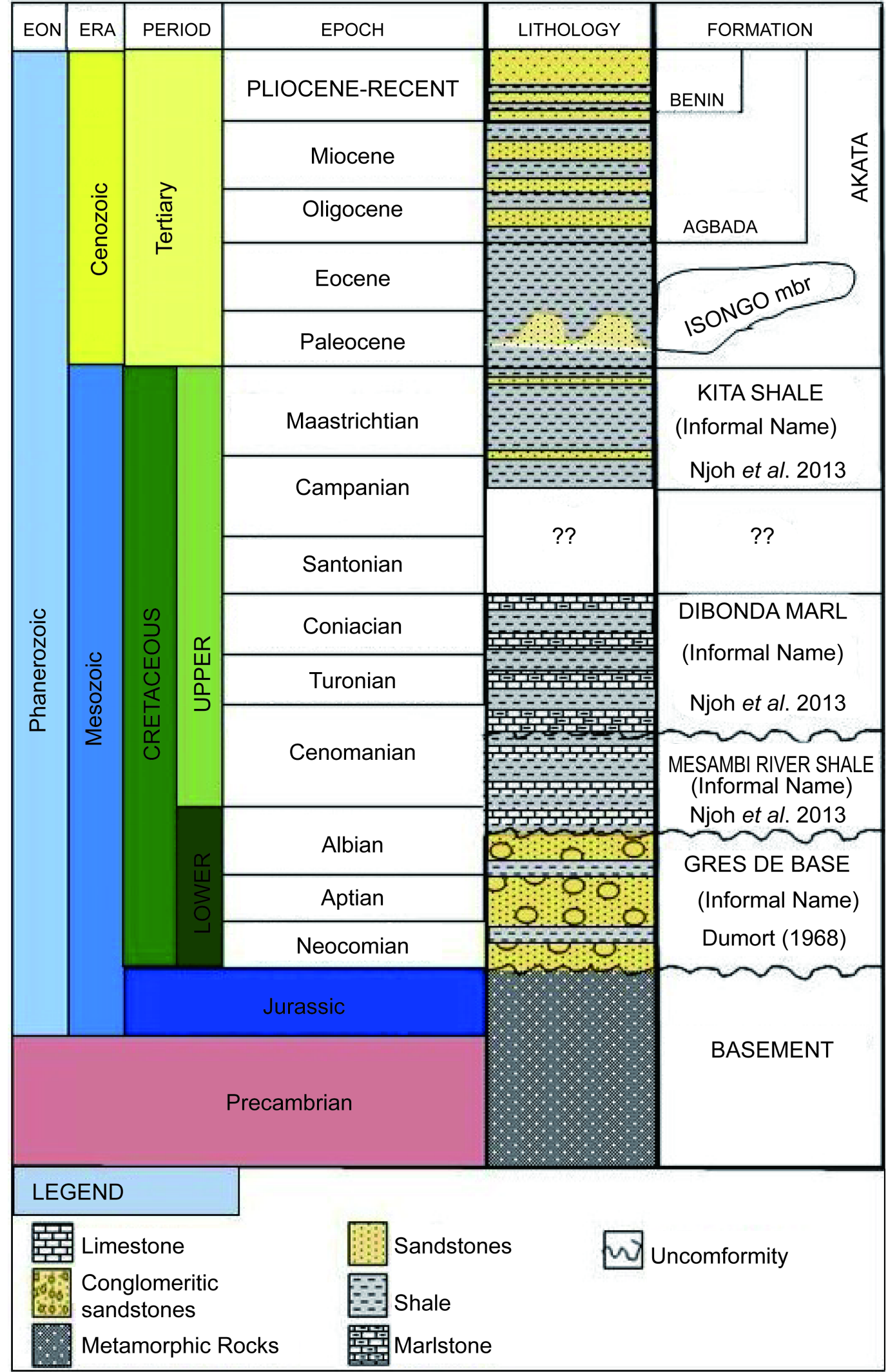

Figure 2. Stratigraphy of the Rio del Rey Basin (modified from [4b]). 
O. A. Njoh, A. J. Taku

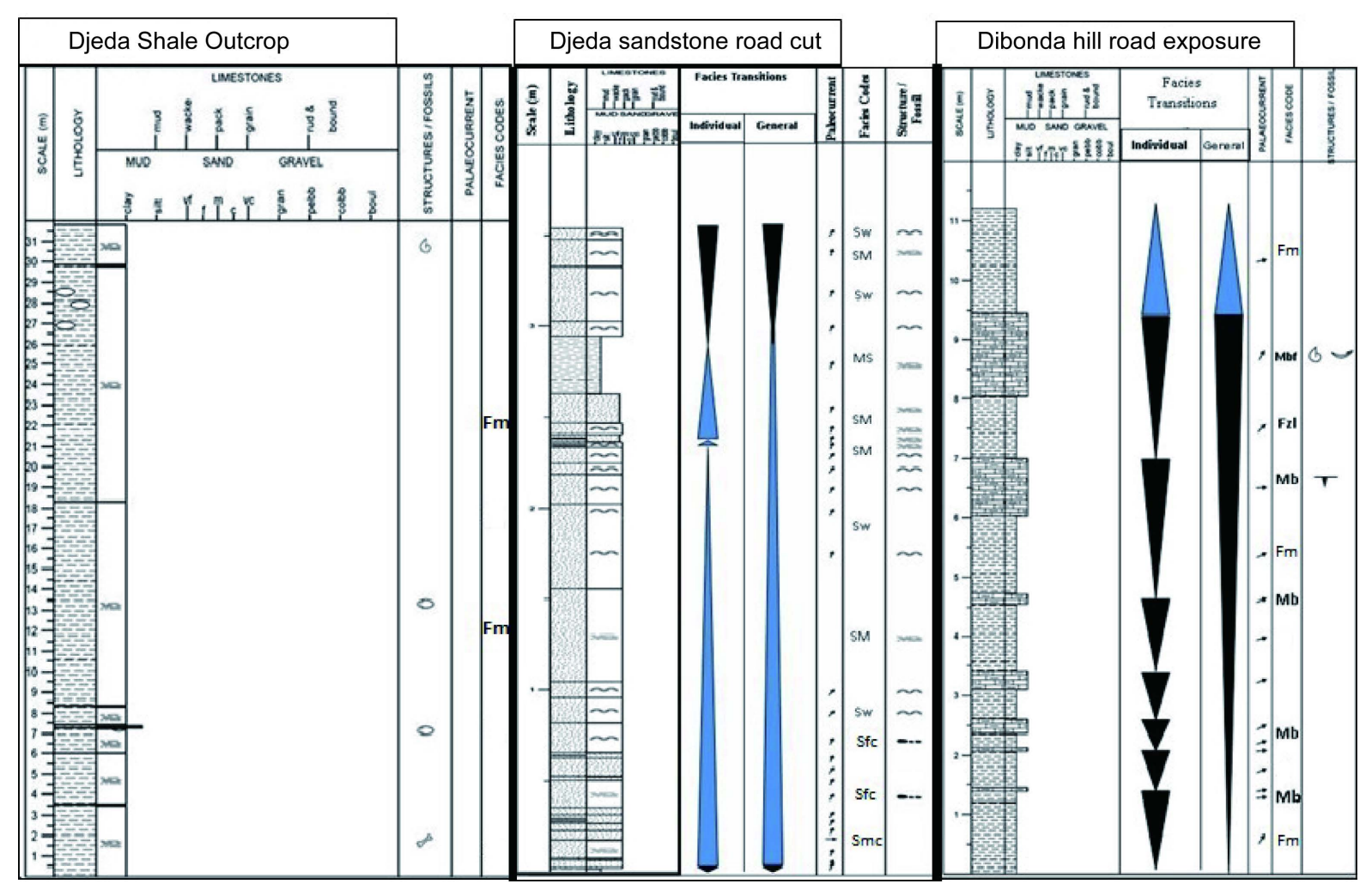

(a)

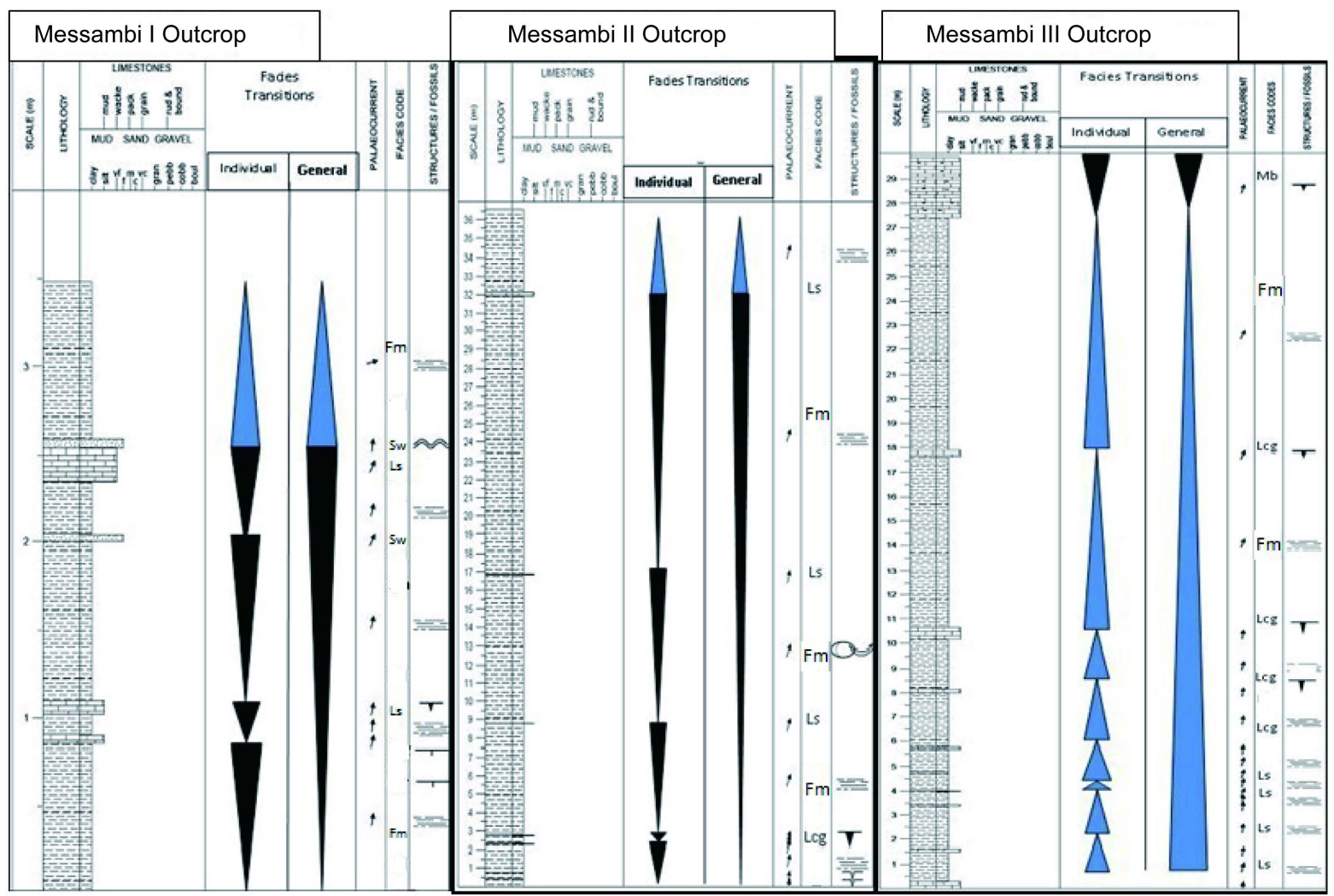

(b)

Figure 3. Lithologic logs for the outcroping sections studied. 
outcrops were developed using a combination of specialized software, including Sedlog 3.0, Photo filter and Microsoft word 2007 (Figure 3(a) \& Figure 3(b)), and all the lithofacies identified were grouped into three facies association from which the depositional environments were inferred.

\section{Results}

\subsection{Facies Descriptions}

Sedimentary rock sequences exposed within the Illor-Dibonda area in the northern portion of the Rio del Rey Basin range from a few centimetres to well over $32 \mathrm{~m}$ in height and some extend laterally over $150 \mathrm{~m}$. The lithology is fairly simple with the shale units generally predominant, constituting about $80 \%$ of the rock types exposed. The shales comprise of thick (meter scale) beds that are intercalated in places by limestones, marlstones, sandstones and concretions.

The major lithologies are shales, limestone marlstone and sandstone out of which eleven lithofacies have been recognized and described from the coarsest (S) to the finest $(\mathbf{F})$. Facies codes were developed following the procedure described in [20] and adapted in [19] [21]-[25] and have been assigned to each facies. Facies analysis gives insight to depositional processes on the basis of lithology, structure, fossil and mineralogical characteristics [11] [23] [24] [26]-[29]. Hence, the depositional settings of the different facies identified were interpreted.

\subsection{Sandstone (Smc) Facies}

Sandstone beds in this area commonly range in thickness between 8 and $50 \mathrm{~cm}$ and made up of principally fine to medium grained, moderately to well sorted, clast-supported predominantly quartz grains that range in shape from sub-angular to rounded with moderate sphericity. The sandstone beds that make up this facies generally occupy the lower part of the Djega roadside-cut section, and also on the upper part of the Messambi II outcrop. The colour ranges from grey to brownish and sometime reddish and dark brown. Thin section analysis of this facies (Figure 4(a) \& Figure 4(b)) shows that the dominant grain types are quartz, which comprise about $90 \%$ of the sandstone matrix, feldspars make up 5\%, and the rest is rock fragments, micas (muscovite) and organic fragments. The quartz grains exhibit straight to strongly undulose extinction. Some samples of this facies contain the greenish mineral glauconite (Figure 4(b)). These sandstones are classified as quartz arenites using the classification scheme of [30].

\subsection{Wave Rippled Sandstone (Sw) Facies}

This facies like the Smc, consists of fine to medium grained sandstones beds that range in thickness between 4 $18 \mathrm{~cm}$, reveal bi-directional asymmetric wave ripple marks (ripple index $=6$ ) that trend SSE. This facies occurs at various levels of the Djega sandstone roadside-cut and also on the upper part of the Messambi II outcrop. Low powered microscopy of crushed samples of this facies show that the constituent grains are generally sub-angular to sub-rounded. Thin section examination shows that the mineralogy of the sandstones is predominated by quartz which shows strong undulose extinction with minor amounts of rock fragments and organic fragments as well glauconitic grains also occur in the rock matrix. Feldspars and micas are absent from this facies. This facies is also termed quartz arenites [31].

\subsection{Sandstone Mudclast (Sfc) Facies}

This is a fine to medium grained pale brown unconsolidated, friable sandstone facies with incorporated mud fragments that occur at the lower part of the Djega sandstone roadside-cut. The facies contains isolated dark grey to black mud petals in the form of mud clast [20] [30], disseminated in friable sandstone. Low powered microscopy of a crushed sample of this facies revealed that the facies is made up of sub-angular to sub-rounded quartz grains with tiny rounded feldspar grains. The facies share very similar physical attributes as the SM facies and is classified as ranging between quartz arenites and feldspathic arenite.

\subsection{Sandstone-Mudstone Couplets (SM) Facies}

The SM facies is made up of numerous repetitive thin to moderate sandstone beds measuring between 2 and 10 $\mathrm{cm}$. These sandstone beds are distinct in that they are generally dark grey to black in colour, frequently separated 

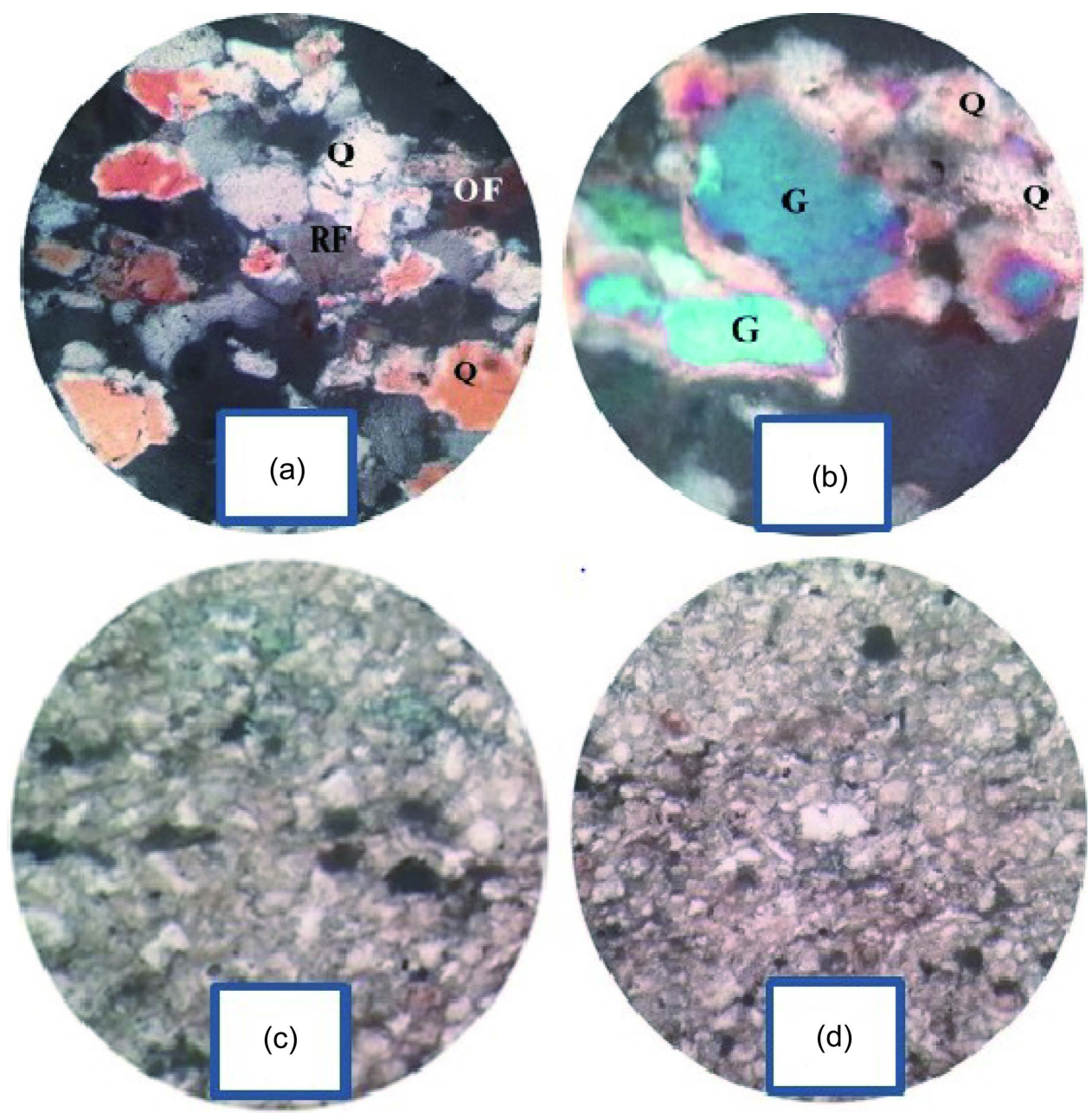

Figure 4. (a) Photomicrograph of the quartz arenites (qtz = quartz, rf = rock fragments, of = organic fragments); (b) Photomicrograph of quartz arenite hosting glauconite ( $\mathrm{G}=$ glauconite); (c) Photomicrograph of the micritic mudstone (marlstone) facies; (d) Photomicrograph of the limestone facies.

by very thin shale beds or laminae. The sandstone beds are composed of fine to medium generally matrix supported grains. A similar facies is described by [22] from which the facies name is derived.

\subsection{Marlstone (Mb) Facies}

$\mathrm{Mb}$ facies comprises low angle dipping marlstone beds with thickness over $200 \mathrm{~cm}$ occurring mainly at the Dibonda Hill roadside exposure (Figure 6) and the uppermost part of the Messambi III outcrop. They are grey in colour and frequently alternate with calcareous shale beds. Thin section (Figure 4(c)) analysis reveals a lime mud matrix with an admixture of very fine grains of clastic materials [32].

\subsection{Fossiliferous Marlstone (Mbf) Facies}

This facies (Figure $5(\mathrm{~g})$ ) is very similar to the Mb facies but is very rich in bivalve shells. It occurs exclusively on the upper part of the Dibonda Hill road exposure as low angle dipping marlstones bed with a light grey colour. It encloses numerous bivalve shells. Many whole bivalve shells were recovered from this bed and were identified after [33]-[35] into two taxa; the Venericardiinae sub-family (Figure 5(e)) and the Exogyra ponderosa (Roemer) species (Figure 5(f)). Several shells could not be recovered whole because they were highly recrystallized with the calcareous rock while others could not be properly cleaned and the surface ornamentations were either masked or destroyed and so identification of those samples down to species level was not possible. 


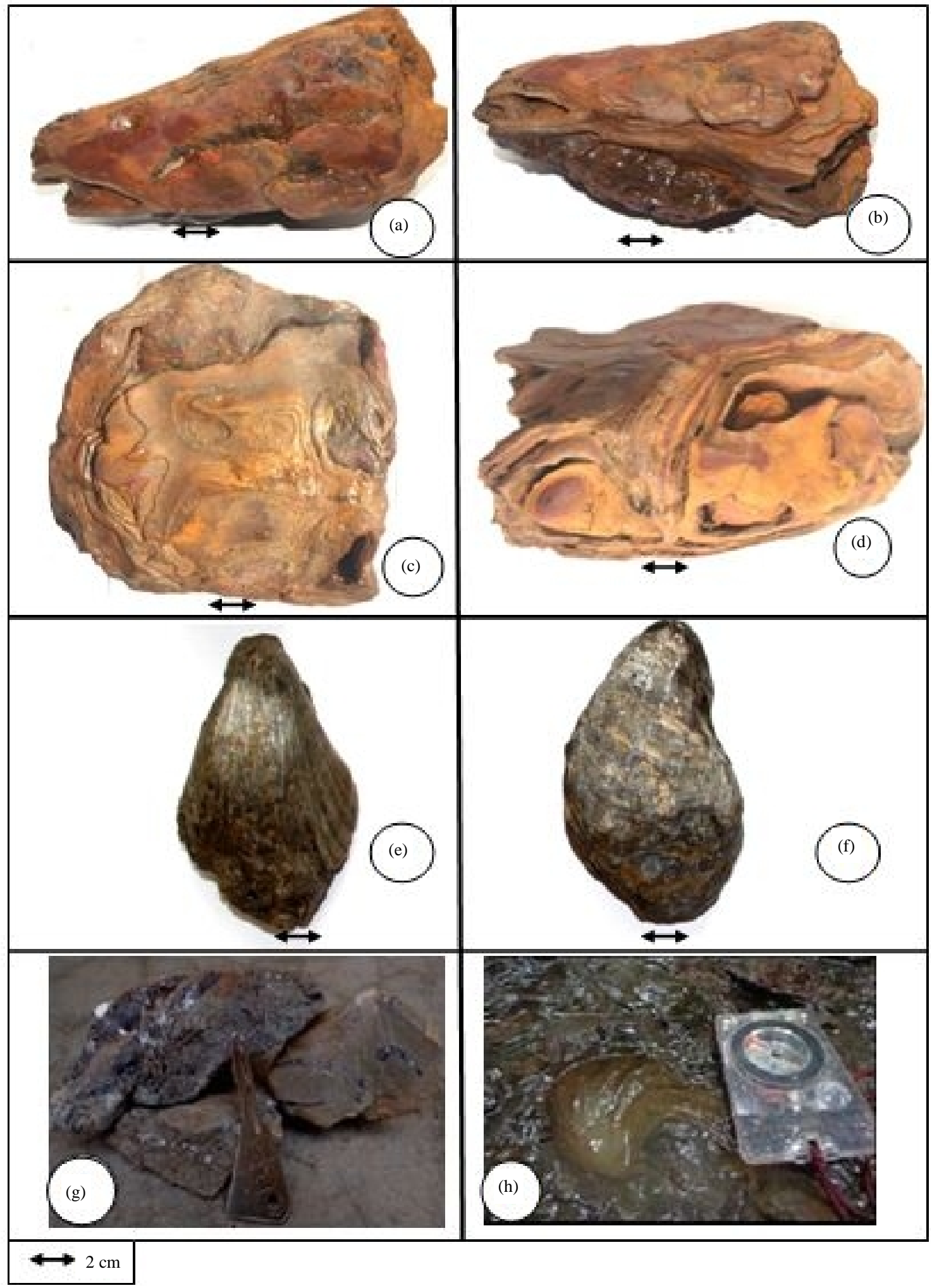

Figure 5. (a) (b) Pictures of the fish head-like fossil; (c) (d) Pictures of the turtle head-like fossil; (e) Picture of the bivalve shell of Venericardiinae subfamily member; (f) Picture of a Exogyra ponderosa (Roemer); (g) Picture of the highly fossiliferous marlstone facies along the Dibonda hill; (h) Picture showing a bivalve mould hosted on the mid segment of the River Messambi I outcrop. 


\subsection{Limestone (Ls) Facies}

This is a limestone facies that is generally whitish to grey in colour and the beds range in thickness from $2 \mathrm{~cm}$ to $18 \mathrm{~cm}$. Apart from the visible somewhat recrystallized calcite needles, these limestone beds do not exhibit any fossils or structures and occur most often than not as intercalations within the thick shale intervals of the outcrops at the banks of River Messambi. At the Messambi I outcrop, the facies occupy mainly the middle and upper parts of the outcrop, forming three beds with thickness ranging from $2 \mathrm{~cm}$ to $6 \mathrm{~cm}$. At the Messambi II outcrop, this facies occurs as a single $18 \mathrm{~cm}$ bed of light grey limestone and it occupies the lower and middle level of the Messambi III outcrop between thick shale beds. Here, they range in thickness from $2 \mathrm{~cm}$ to $8 \mathrm{~cm}$. This section (Figure 4(d)) analysis of this facies reveals that it is predominantly made up of very tiny calcite grains. This facies is classified as microcrystalline carbonates following the carbonates classification scheme of [36].

\subsection{Massively Bedded Shale (Fm) Facies}

Most of the outcrops in the study area (except the Djega sandstone roadside-cut) expose dark grey to black shale facies that are massive to poorly bedded, indurated and slightly fissile to very friable and fissile at some intervals. Where they occur these thick beds are intercalated by the limestone and sandstone facies, sometime by marlstone. Some beds could be as thin as less than $10 \mathrm{~cm}$ while other beds are of meter scale. The thick beds are usually very indurated and show very faint or no fissility while other interval are very fissile to friable. At the lower part of the Djega outcrop, nodular beds and concretions ranging between $5 \mathrm{~cm}$ and $12 \mathrm{~cm}$ occur frequently but at irregular intervals within the thick beds. The very fissile beds can be seen at the upper section of this outcrop near the lone road traversing this study area. The fissile shale beds are particularly black in colour and pyritized. This outcrop measures up to about $27 \mathrm{~m}$ in thickness, poorly to moderately bedded and the beds generally dip at about $10^{\circ}$ to the southwest.

Several fish (Figure 5(a) \& Figure 5(b)) and turtle-like (Figure 5(c) \& Figure 5(d)) fossils heads were recovered from the lower part of the outcrop. These fossils measure between $10 \mathrm{~cm}$ and $12 \mathrm{~cm}$ in length and $8 \mathrm{~cm}$ in width have been so altered and ferrugenized beyond any reasonable identification and the rest of the body skeletons were not encountered. However, the fish heads are seen to tapper and elongated in the mouth region where teeth-likes structures protrude but not very distinct. The eye spots of especially the turtle-like heads are more or less distinct and the operculum region can be seen.

On the Dibonda Hill roadside-cut, the facies occur as grey to dark grey well bedded $12 \mathrm{~cm}$ to $150 \mathrm{~cm}$ thick shale beds that are faintly fissile and are alternating at regular intervals with very fossiliferous marlstones from which some of the bivalve shells were collected (Figure 6). The facies also occurs on the outcrops along the banks of River Messambi as grey to dark-grey, indurated and highly fissile shale beds ranging from $12 \mathrm{~cm}$ to $250 \mathrm{~cm}$ thick, regularly intercalated by thin to moderately thick limestone and sandstone beds. On the upper part of the Messambi I outcrop, they host a number of bivalve moulds (Figure 5(h)) and spherical calcite concretions.

\section{Discussions}

\subsection{Facies Associations and Depositional Environments}

In the present study, the lithofacies identified from field descriptions, Laboratory (Granolumetric and petrographic) analyses and paleontological data obtained were grouped into three facies associations from which the depositional environments of the studied sequences were inferred. These depositional environments range from marginal marine tidal/shoreface to open shallow marine setting.

\subsubsection{Deep Marine Deposits (Middle Neritic)}

The massively bedded shale $(\mathrm{Fm})$ facies, marlstone $(\mathrm{Mb})$ facies, fossiliferous marlstone (Mbf) facies, limestone (Ls) facies and limestone with clints and grikes (Lgc) facies, represent the lithofacies that were deposited in an open marine setting. The Djega shale outcrop (Figure 3(a)) measures about $27 \mathrm{~m}$ in height and is characterized by dark-grey to black, massive to very fissile shale beds that most have been deposited in a calm relatively deeper marine environment with reduced oxygen concentration (below the storm wave base), probably a middle neritic sub environment. A similar environment is also here inferred for the over $30 \mathrm{~m}$ sequence of black highly indurated shale beds exposed along the banks of River Messambi (Messambi I, downstream). This part of the 

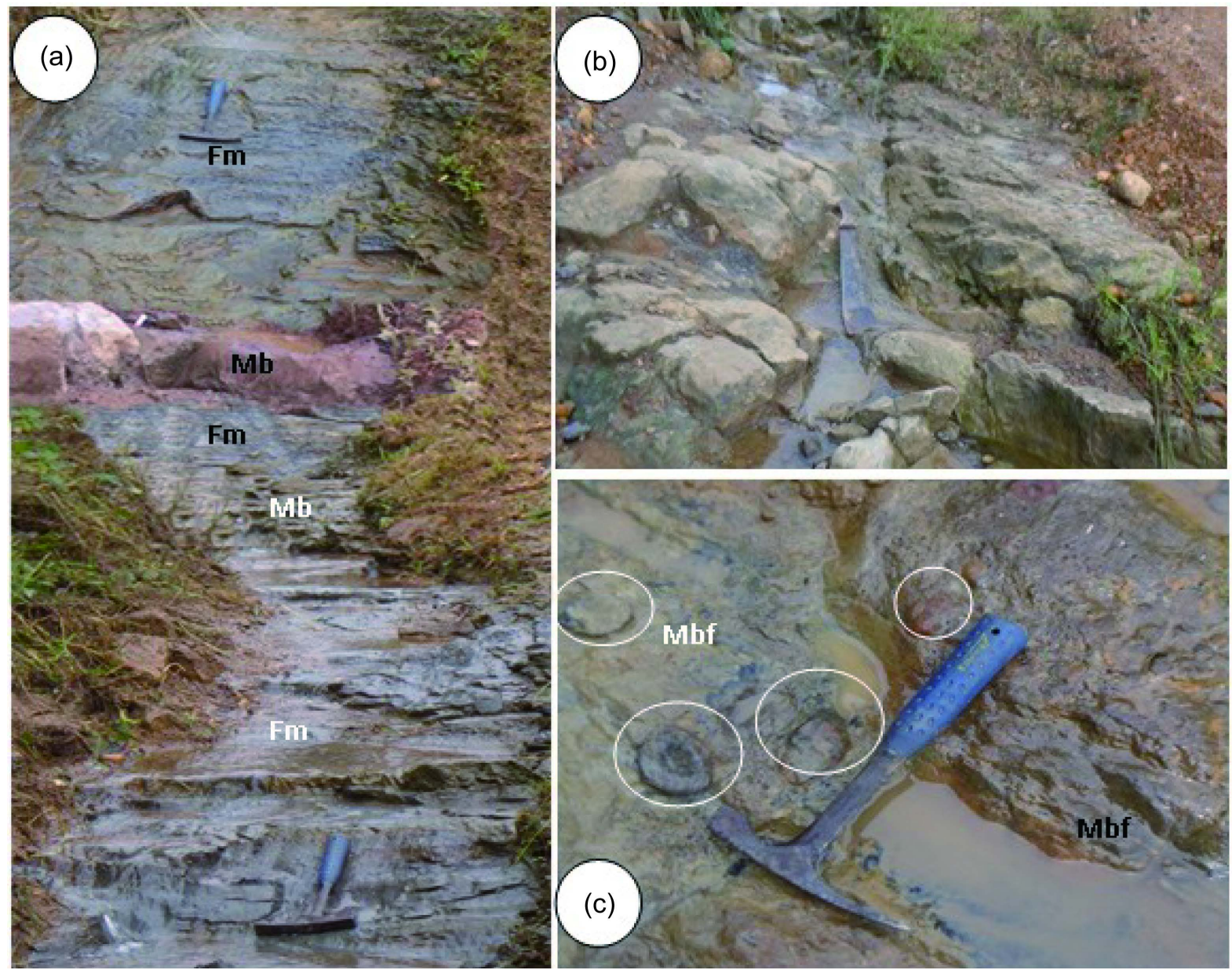

Figure 6. Picture illustrating the Dibonda Hill road side exposure.

marine environment is calm and less sensitive to wave processes, allowing the deposition of organic rich black shale under anoxic conditions [29] [31] [37].

\subsubsection{Open Shallow Marine Deposits}

The Dibonda roadside cut exposes a generally alternating sequence of dark-grey calcareous shales and marlstone beds while the series of limestone beds that equally alternate the thick shale units at all the three outcrops along River Messambi (Messambi I, II and III) respectively represent deposition on a very shallow shelf environment. The limestone and marlstone facies are generally composed of lime mud (microcrystalline) known to have been precipitated on the open sea floor especially in tropical latitudes [38] [39]. The frequent alternations between the carbonate rocks and the shales also indicate frequent fluctuations in sea level. As such, the dark-grey to black thick shale beds were deposited in a deeper setting and when the sea level shallows, the carbonate rocks are deposited [37] [40]-[43]. This is true for coasts that were characterized by successive rise and fall in sea level. [43] described a similar depositional setting for the New Netim Marlstones in the neighbouring Calabar Flank which is very similar to the Dibonda Marlstone unit in terms of facies and age [4].

The massive sandstone (Sm) facies (Figure 7) is generally assessed to be moderately mature and thus represent a further reduction in water depth (inner neritic) with only moderate currents and the glauconite grains observed in thin sections of the sandstones that intercalate the shale facies in some of the outcrops points to deposition in a marine setting. Glauconite is known to be precipitated and reworked only in the marine setting [11] [37].

\subsubsection{Intertidal/Shoreface Sandstone Deposits}

This deposit is characterized by the facies association consisting of the wave rippled sandstones with mud 


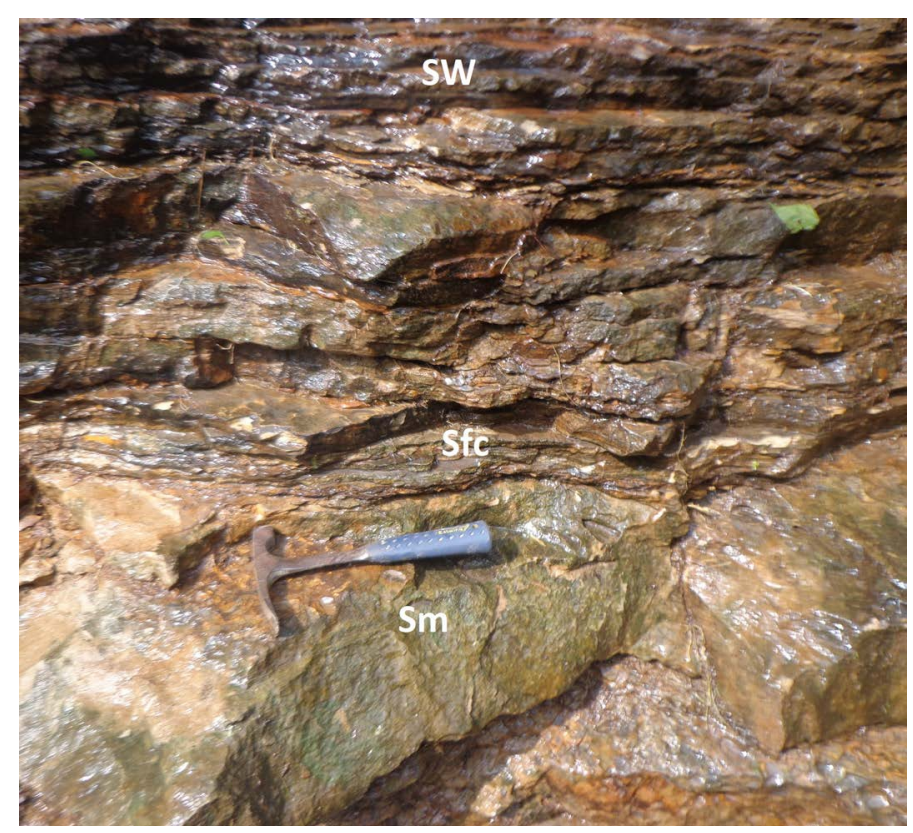

Figure 7. Sandsone, shale and mudstone intercalations observed at the Djega roadside cut section.

drapes, intercalated by thin beds and laminations of dark grey to black mudstone represented by the Djega sandstone roadside cut. According to [37] [39], the characteristics of this sandstone facies represent near shore marine to tidal channels and shoreface environments. [22] [25] [29] [37], described the facies assemblage characterized by wave rippled sandstones intercalated by thin beds or laminations of mudstone as typical wash over, flood tidal to ebb-tidal deposits in the intertidal to shallow marine setting. The massive sandstone (Sm) facies is only moderately mature, represent are shallow probably inner neritic (shoreface) environment, affected only by weak currents. These sandstones also contain gluaconite grains thought to have been reworked from deeper marine environments [37].

From the discussion above, the facies association consisting of thick intervals of dark grey to black shale intercalated by both sandstones, siltstones and carbonate rocks exposed at the Dibonda hill and the River Messambi outcrops, have been characterized as deposits of an environment which experienced continuous sea level fluctuations that will allow the deposition of both clastics and carbonates materials due to repetitive shallowing and deepening. The thick black shale beds that characterize the lower section of the Djega outcrop, containing both the micro and mega marine fossils points to an environment that was receiving large quantities of sediments supply on an open relatively deeper marine platform that was rapidly sagging.

All the outcrops studied are made up of facies having either simple bedset or composite bedset configurations. The simple bedsets or cosets represented by alternating beds of shale and sandstones as in the MS and SM facies characterizes repetitions of genetically related conditions in a given depositional environment, while the composite bedsets or cosets represent repeated alternations of two sets of conditions occurring in a given sedimentary environment [44] [45]. This observation is consistent with the thinking that sea level rise and fall could have been the main driving force of deposition within the study area.

\subsection{Paleontology}

Fossils recovered from ancient sedimentary units most often than not, constitute a quick means by which the environments in which the units were deposited can be inferred. Paleontological materials recovered from the sediments studied here include: fish and turtle heads, bivalves and moulds (Figure 5 and Figure 6). Previous authors [8] [9] have recovered foraminifera from both Djega and Dibonda outcrops and palynomorphs from downstream Mesambi II which were independently used to date these sequences as Turonian-Coniacian, Campanian-Maastritchtian and Albian-Cenomanian, respectively.

Although, the fish and turtle heads recovered particularly from the lower section of the Djega shale outcrop 
were so altered that proper identification is rather impossible, their sizes represent however the remains of two distinct ancient large animals. Several species of fish and tortoise are known to have colonised ancient seas in which they were good swimmers even before the Cretaceous. These organisms were swimmers therefore, a rough imagination of their sizes from the heads (Figure 5), indicate that swimming would have been most effective in a water column of considerable depth like and open marine shelf, middle neritic. The presence of these fossils, support the inference of an open relatively deeper marine depositional environment for the Djega massive shales.

Several marlstone and shale beds from the Dibonda and Messambi river outcrops were very fossiliferous with both body-(bivalves) and trace fossils (moulds). As noted at some intervals the bivalves shells were in places, so visibly crowded. Due to the process of recrystallization, many of the shells could not be collected and some were broken. This marred the proper identification, however, only one species (Exogyra ponderosa) and one sub-family (Venericardiinae), as described by [33] [40] were identified with certainty. Bivalves generally inhabit the shallow parts of a water body, as have been described, they are numerous, particularly in the marlstones, supporting their shallow environment of deposit.

\subsection{Petrographic and Granulometric Analyses}

Petrographic (thin sections) and granulometric (microscopy) analyses were performed on a few selected samples to better determine the microscopic minerals and textures in order to assist the analyses of the various facies. Apart from the cementing materials, quartz was observed to predominant, then the feldspars and in some, biotite however, the presence of the mineral glauconite in all of the sandstone samples is very significant. [11] [37] have noted that glauconite is precipitated on deeper marine floors and reworked by currents and waves to shallow and marginal areas. Significantly, the glauconitic mineral grains commonly present in the thin sections confirm that the sandstones are marine even though deposited in shallow to marginal environments.

\section{Petroleum Potential}

In order to appreciate the petroleum potentials of this part of the Rio del Rey Basin, studies as this and many others are required. Structural and stratigraphic investigations for example, are of utmost importance as would lead to the understanding of the character, distribution and the structural disposition of the sandstones and shales. It will assist with preliminary information on the reservoir character of the sandstones and the organic facies of the shales present including the historic evolution of the basin and the possible timing of the generation, migration and accumulation of petroleum. A brief insight of the physical characters, the stratigraphic arrangement and depositional environments of the rock units studied reveals a possible petroleum system.

[46] described a petroleum system to encompass a pod of active source rock, reservoir rock and migration pathways, seal rock and traps and emphasized that the processes of generation, migration and accumulation must be active and all the essential elements must be placed in time and space. This basin is current a prolific hydrocarbon producer but doing so from exclusively its offshore Tertiary units. These authors are here kind to appraise the petroleum system and therefore the potential of the onshore Cretaceous interval of the basin.

\subsection{Source and Sealing Rocks}

[47], carried out geochemical analyses (TOC and Rock-Eval Pyrolysis) of the black shales exposed in this area and revealed TOCs up to $0.9 \mathrm{wt} \%$ from generally kerogen type III and IV which are gas-prone and few samples showed thermal maturity within the oil window. Thick sequences of up to about $30 \mathrm{~m}$ of these black shales that are source rocks are present in this study area. Very black fissile to friable shales are exposed at the Kita Junction near Masure village, though have not been subjected to any geochemical studies were noted [9] to be of very high organic content. Subsurface samples of this area are expected to yield higher values since the present figures were obtained from surface rocks which have undergone repeated weathering and uplift. The shale beds that sandwich the sandstones do not only act as source rocks but also as regional seals while other seals consist of the inter-tidal mud drapes bounding the sometimes isolated sandstone bodies.

\subsection{Reservoirs}

The various stratigraphic sections encountered in this area expose sandstone intervals of varying thicknesses and 
physical characteristic and so varying reservoir qualities. The sandstones have been ascertained to have been deposited in a shallow marine to inter tidal environments of deposition wherein a variety of sand bodies abound including tidal and ebb tidal fans. The rocks of this study area are known to be directly overlying those of the fluvio-lacustirne basal conglomeratic sandstone unit (informally known as the Bafaka Sandstones) of this basin. Rocks of this unit are well exposed as high and steeply folded sometimes incised hills of the Bafaka area. Although, no reliable scientific study of their reservoir properties have been carried out, teaching practical work with students indicate plausible porosity percentages as would have been expected from channel sand deposits.

Samples collected from the sandstone intervals exposed at the Djega roadside cut and Dibonda hill were subjected to porosity test and using the simple porosity formula; $\varnothing=\frac{V p(\mathrm{ml})}{V s+V p(\mathrm{ml})} \times 100$, where $\varnothing$, is porosity, $V s$ and $V p$ are solid and pore volumes respectively in millilitres (ml). The data obtained revealed porosity of these sandstones ranged from $25.73 \%$ described as good to $35.06 \%$ describe as very good. Lithofacies descriptions and petrographic studies of the same rock samples in thin section, indicated only moderate sorting of grains and mineralogic immaturity, which will most probably affect their permeabilities.

\subsection{Trapping Mechanisms}

It is very evident from the sequences studied that stratigraphic, structural and most probably a combination of both traps exist. Stratigraphic traps are normally formed following the depositional style of the basin and can be depicted from the study of the depositional sequences. These sequences revealed many sandstone beds, continuous or discontinuous, sand-wished in between shale beds as described from the Messambi River outcrop and Dibonda hill. The intertidal environment is characterized by small sand bodies like the tidal fans (tidal- and ebb tidal fans) generally draped in mud exemplified by the Djega roadside cut section. On the other hand, structural traps are formed in close relation to the tectonic evolutionary history of the basin including pre-, syn- and post depositional tectonic deformations. Non tectonic syn-depositional deformations like the highly faulted roll-over anticlinal structures and mud diapers characterize the deltaic Tertiary deposits of this basin.

Dip measurements show that, the rocks of this area have been highly folded, the outcrop Messambi I downstream of the river pronouncedly show folded limbs that dip between $18^{\circ}-20^{\circ}$ in two opposite directions. A normal fault is very visible at the Messambi II outcrop while other fractures are encountered throughout the area.

\subsection{Petroleum System}

Although an onshore well is still to be developed and produced in this part of the Rio del Rey Basin, a proper petroleum system is thought to be very much in place. In this stratigraphic study, the shales encountered do not only indicate good source rock characters, they are also voluminous as seen at the Djega and Messmbi I outcrops which respectively are about $30 \mathrm{~m}$ thick in outcrop. They are supposed here to constitute the pod of active source rocks. The sandstones are abound and in very close and appropriate relationship with the shale intervals. The quality of these sandstones from lithologic, petrographic and preliminary petrophysical investigations, undoubtedly describe them as good to very good reservoirs. Some of these sand beds are seen sandwiched in thick shales which provide the required seals while themselves, constitute migration pathways. It is expected therefore that petroleum (oil or gas) has been generated, migrated and has been trapped under the stratigraphic and structural conditions as seen above.

\section{Conclusions}

Previous workers have emphasized the rarity of outcrops within this study area; however, this paper describes several thick sequences of sedimentary rock units outcropping along the northern flank of the Rio del Rey Basin. Integrated lithologic, paleontologic, granulometric and petrographic data were analyzed from the field and laboratory studies. Eleven (11) lithofacies were identified from which three (3) lithofacies associations were grouped to reflect three depositional environments: open deeper marine middle neritic, open shallow marine and intertidal/shoreface inner neritic, for the sequences studied. As shown on the graphic logs, the outcrops depict generally a coarsening upward set of sequences, representing the different depositional environments as described above. Repeated beds or intervals represent short periods of minor sea level rise and fall. 
Although foraminifera and exclusive marine micro-organisms have earlier been recovered from the fine grained rock units within this area, asymmetrical (bi-directional) ripples, glauconite grains and paleontological data support the relatively shallow marine origin of these sediments. There are also strong indications of the existence potential if not of effective source rocks, good reservoir rocks and migratory pathways and both stratigraphic and structural trapping conditions within this study area, representing a good petroleum system [48]-[50]. The results presented in this paper should open the way forward for further studies related to the petroleum exploration activities in this part of the basin which has hitherto, been neglected.

\section{Conflict of Interest}

This research is an original work that has been carried out by us and we the authors declare that there is no conflict of interests regarding the publication of this manuscript. We equally declare that our manuscript is not published elsewhere and is not currently under consideration by another journal published by ScienceDirect or any other publisher.

\section{References}

[1] Coughlin, R.M., Bement, W.O. and Maloney, W.V. (1993) Petroleum Geology of the Deltaic Sequence, Rio del Rey Basin, Offshore Cameroon. AAPG International Conference and Exhibition, The Hague, 17-20 October 1993.

[2] Njoh, O.A. (2007) Upper Cretaceous Foraminiferal Biostratigraphic Correlations; Douala and Rio del Rey Basins (S.W. Cameroon) and Calabar Flank (S.E. Nigeria). Unpublished Doctoral Dissertation, University of Calabar, Nigeria, 264 p.

[3] British High Commission Yaounde (2012) Report on the Oil and Gas Sector of Cameroon. Ministry of Mines and Energy, $31 \mathrm{p}$.

[4] Njoh, O.A., Obiosio, V. and Agyingi, C. (2013).Campano-Maastrichtian Foraminifera from Onshore Sediments in the Rio del Rey Basin, Southwest Cameroon. Journal of African Earth Sciences, 79, 157-164. http://dx.doi.org/10.1016/j.jafrearsci.2012.11.009

[5] Reyment, R.A. (1959) Afrobolivina, a New Species and Bolivina in the Upper Cretaceous and Lower Tertiary of West Africa. Stockholm Contribution to Geology, 3, 1-57.

[6] Belmonte, Y.C. (1966) Stratigraphie du bassin sidementaire du Cameroon. Proceeding on 2nd West African Micropale ontology Colloquium, Ibadan, 1-5 September 1966, 7-24.

[7] Dumont, J.C. (1968) Notice explicative sur la feuille Douala Ouest (1/500 000). D.M.G. Yaounde, Cameroun, 69 p.

[8] Njoh, O.A. and Petters, S.W. (2008) Upper Cretaceous Foraminifera of the Rio del Rey Basin, South West Cameroon. Africa Geosciences Review, Special Publication, 1 \& 2, 51-63.

[9] Njoh, O.A., Bassey, E.A., Ama, J.E. and Agbor, V.W. (2013) Palynostratigraphy of Early Cretaceous Deposits from the Rio del Rey Basin, S.W Cameroon. Journal of the Cameroon Academy of Science, 11, 51-61.

[10] Petters, S.W. (1993) Gulf of Guinea Planktonic Foraminifera, Biochronology and Geological History of the South Atlantic. Journal of foraminifera Research, 13, 32-59. http://dx.doi.org/10.2113/gsjfr.13.1.32

[11] Murat, R.C. (1972) Srtatigraphy and Paleogeography of the Cretaceous and Lower Tertiary in Southern Nigeria. In: Dessauvagie, T.F. and Whiteman, A.J., Eds., African Geology, Ibadan University Press, Ibadan, 251-266.

[12] Reyment, R.A. (1955) Cretaceous Ammonites of Southern Nigeria and Southern Cameroon. Bulletin of Geological Survey of Nigeria, 25, 112.

[13] Regnoult, J.M. (1986) Synthèse Géologique du Cameroun, Ministère des mines et de l'énergie. Direction des Mines et de la Géologie, Sodexic Yaoundé, 119 p.

[14] Nguene, F.R., Tamfu, S., Loule, J.P. and Ngassa, C. (1992) Paleoenvironment of the Douala/Kribi Campo Sub-Basins in Cameroon, West Africa. Géologie Africain; Colloque Géologique, 129-139.

[15] Teisserenc, P. and Villemin, J. (1989) Sedimentary Basin of Gabon-Geology and Oil Systems. In: Edwards, J.D. and Santogrossi, P.A., Eds., Divergent/Passive Margin Basins, Volume 46, American Association of Petroleum Geologists Memoir, 117-199.

[16] Meyers, J.B., Rosendahl, B.R., Groschel-Becker, H., Austin Jr., J.A. and Rona, P.A. (1996) Deep Penetrating MCS Imaging of the Rift to Drift Transition, Offshore Douala and North Gabon Basins, West Africa. Marine and Petroleum Geology, 13, 791-835. http://dx.doi.org/10.1016/0264-8172(96)00030-X

[17] Benkhelil, J., Giresse, P., Poumot, C. and Ngueutchoua, G. (2002) Lithostratigraphic, Geophysical and Morpho-Tectonic Studies of the South Cameroon Shelf. Marine and Petroleum Geology, 19, 499-517. 
http://dx.doi.org/10.1016/S0264-8172(02)00002-8

[18] Lawrence, S.R., Munday, S. and Bray, R. (2002) Regional Geology and Geophysics of the Eastern Gulf of Guinea (Niger Delta to Rio Muni). The Leading Edge, 21, 1113-1117. http://dx.doi.org/10.1190/1.1523752

[19] Ntamak-Nida, M.J., Bourquin, S., Makong, J.-C., Baudin, F., Mpesse, J.E., Ngouem, C.I., Komguem, P.B. and Abolo, M.G. (2010) Sedimentology and Sequence Stratigraphy from Outcrops of the Kribi-Campo Sub-Basin: Lower Mundeck Formation (Lower Cretaceous, Southern Cameroon). Journal of African Earth Sciences, 58, 1-18. http://dx.doi.org/10.1016/j.jafrearsci.2010.01.004

[20] Tucker, M.E. (2011) Sedimentary Rocks in the Field: A Practical Guide. 4th Edition, John Willey and Sons Ltd., Chichester, 85-104.

[21] Nichols, G. (2009) Sedimentology and Stratigraphy. Blackwell Science Ltd., London, 335 p.

[22] Slomka, T. and Slomka, E. (2001) Sequences of the Lithofacies and Depositional Intervals in the Godula Beds of the Polish Outer Carpathians. Annales Societatis Geologorum Poloniae, 71, 35-42.

[23] Miall, A.D. (1977) Lithofacies Types and Vertical Profile Models in Braided River Deposits: A Summary. In: Miall, A.D., Ed., Fluvial Sedimentology, Geological Survey of Canada, Calgary, 597-604.

[24] Miall, A.D. (2000) Principles of Sedimentary Basin Analysis. 3rd and Enlarged Edition, Springer-Verlag, Berlin, 616 p. http://dx.doi.org/10.1007/978-3-662-03999-1

[25] Reading, H.G. (1996) Sedimentary Environments: Processes, Facies and Stratigraphy. 3rd Edition, Blackwell, Oxford, $689 \mathrm{p}$.

[26] Tucker, M.E. (2003) Sedimentary Rocks in the Field. 3rd Edition, John Willey and Sons Ltd., Chichester, 236 p.

[27] Tucker, E.M. and Wright, V.P. (1990) Carbonate Sedimentology. Blackwell Science Ltd., Oxford, 486 p. http://dx.doi.org/10.1002/9781444314175

[28] Potter, P.E., Maynard, J.B. and Pryor, W.A. (1980) Sedimentology of Shale. Springer Verlag, New York, 610 p. http://dx.doi.org/10.1007/978-1-4612-9981-3

[29] Boggs Jr., S. (2006) Principles of Sedimentology and Stratigraphy. 4th Edition, Pearson Education Inc., Upper Saddle River, 662 p.

[30] Boggs Jr., S. (2009) Petrology of Sedimentary Rocks. 2nd Edition, Cambridge University Press, New York, 600 p. www.cambridge.org/9780521897167 http://dx.doi.org/10.1017/cbo9780511626487

[31] Reading, H.G. (2001) Clastic Facies Models: A Personal Perspective. Bulletin of the Geologic Society of Denmark, 48, 101-125.

[32] Folk, R.L. (1980) Petrology of Sedimentary Rocks. Hemphill Publishing Company, Austin, 184 p.

[33] Davies, A.M. (1962) An Introduction to Paleontology. 3rd Edition, Murby, London, 341 p.

[34] Pickett, E.T. (1972) Guide to Common Cretaceous Fossils of Delaware. University of Delaware, Delaware Geological Survey, Report of Investigations No. 21, 26 p.

[35] Noble, S. (2013) Cretaceous Fossil Gallery. Cretaceous Bivalves from Oklahoma. Oklahoma Museum of Natural History, $511 \mathrm{p}$.

[36] Dunham, R.J. (1962) Classification of Carbonate Rocks According to Depositional Texture. In: Ham, W.E., Ed., Classification of Carbonate Rocks, AAPG, Tulsa, 108-121.

[37] Nichols, G. (2009) Sedimentology and Stratigraphy. Blackwell Science Ltd., London, 335 p.

[38] Selley, R. (2000) Applied Sedimentology. Academic Press, San Diego, 523 p.

[39] Davis, R.A. (1992) Depositional Systems: An Introduction to Sedimentology and Stratigraphy. Prentice-Hall Inc., Upper Saddle River, 604 p.

[40] Dall, W.H. (1903) Contributions to the Tertiary Fauna of Florida (Part 6). Transactions of the Wagner Free Institute of Science of Philadelphia, 3, 1219-1654.

[41] Cooks, E.H. and Corboy, J.J. (2003) Great Basin Paleozoic Carbonate Platform: Facies, Facies Transitions, Depositional Models, Platform Architecture, Sequence Stratigraphy, and Predictive Mineral Host Models. Field Trip Guidebook-Metallogeny of the Great Basin Project, 17-22 August 2003, USGS, Open-File Report 2004-1078.

[42] Tucker, E.M. and Wright, V.P. (1990) Carbonate Sedimentology. Blackwell Science Ltd., Oxford, 486 p. http://dx.doi.org/10.1002/9781444314175

[43] Essien, U.N. and Bassey, D.E. (2012) Lithostratigraphy, Microfacies Succession, Sequence Stratigraphy and Depositional Environments of the New Netim Formation, Calabar Flank, South Eastern Nigeria. International Journal of Basic and Applied Sciences, 12, 6-19. 
[44] Collinson, J.D. and Thompson, D.B. (1989) Sedimentary Structures. 2nd Edition, Chapmann \& Hall, London, 207 p.

[45] Leeder, M.R. (1982) Sedimentology: Process and Products. Chapmann \& Hall, London, 344 p.

[46] Magoon, L.B. and Dow, W.G. (1994) The Petroleum System. In: Magoon, L.B. and Dow, W.G., Eds., The Petroleum System-From Source to Trap, AAPG Memoire 60, 3-24.

[47] Nya, P.P. (2014) Source Rock Geochemical Analysis of the Cretaceous Black Shales, Onshore Rio del Rey Basin, South-West Cameroon. Master's Thesis, Department of Earth Sciences, University of Dschang, Dschang, 74 p.

[48] Bjorlykke, K. (2010) Petroleum Geosciences: From Sedimentary Environments to Rock Physics. Springer, Berlin, 508 $p$.

[49] Beckmann, H. (1976) Geological Prospecting of Petroleum. Geology of Petroleum. Ferdinand Enke Verlag, Stuttgart, $183 \mathrm{p}$.

[50] Agyingi, C.M., Foba, J.F., Epanty, A.F., Zisuh, F.A. and Ongbwa A.Z. (2006) Carbonate Resources of Cameroon and Potential Applications. International Journal of Natural and Applied Sciences, 2, 57-66. 